\title{
NEURYDYNAMIC FEATURES OF YOUNG PEOPLE WITH DIFFERENT DURATION OF VESTIBULAR ILLUSION
}

\author{
Stepan Vadzyuk ${ }^{1}$ \\ vadzyuk@tdmu.edu.ua \\ Roman Shmata \\ roman@tdmu.edu.ua \\ ${ }^{1}$ Department of physiology with the basios of bioethics and biosafety \\ I. Horbachevsky Ternopil National Medical University \\ 1, Voli sq., Ternopil, Ukraine46001
}

\begin{abstract}
The article deals with neurodynamic features in persons with different duration of vestibular illusion of rotation. The review of the literature concludes that the time of arbitrary reactions is ensured by a high level of integrative activity of nerve formations. Also, data on the effect of rotation test on the indicators of vestibulo-sensory reactions of young fighters-all-rounders and on the sensorimotor reactivity and success of flight training are given. The study of sensorimotor reactions revealed that the longest latency periods were in the people with very long vestibular illusion against rotation. Based on the obtained results, it was concluded, that the features of neurodynamic processes in persons with long duration of vestibular illusion of rotation, in the conditions of excitement of the vestibular analyzer, occur to a greater extent by increasing the duration of motor reactions and increasing the time of the reflex response.
\end{abstract}

Keywords: vestibular analyzer, neuro-dynamic properties, sensor-motor reaction, latency period, rotational test.

DOI: $10.21303 / 2504-5695.2019 .001062$

\section{Introduction}

There are enough papers in the scientific literature to study the time of arbitrary reactions, which are ensured by a high level of integrative activity of nerve formations $[1,2]$. In addition, some authors have studied the dependence of reaction time on factors of training, gender, age and various effects on the body. There are studies that present certain characteristics of sensor-motor responses in different ages $[3,4]$. It is also known, that irritation of the vestibular analyzer causes slowing of the speed of movement, impaired coordination and deterioration of visual perception, significantly affects the indicators of attention [5]. Therefore, there is an evidence of the effect of rotational testing on indicators of vestibular-sensory responses of young all-round fighters and sensor-motor reactivity and success of flight training. The authors note the greatest influence of rotational testing on the vestibular illusion rate of rotation in untrained children and the high correlation dependence of flight training on the individual typological properties of the higher departments of the central nervous system [6, 7]. However, the question of the effect of vestibular loading on sensor-motor response in individuals with different duration of vestibular illusion of anti-rotation remains unexplored.

Aim: to study the neurodynamic features in individuals with different duration of vestibular illusion of rotation.

\section{Materials and methods}

\section{1. Organization of the research}

We surveyed 60 students aged 18-19 years. When performing the work, the observance of the patient safety rules, the preserved rights and canons of human dignity, as well as the moral and ethical standards in accordance with the basic provisions of the GSP (1996) of the Council of Europe Convention on Human Rights and Biomedicine (dated 04.04.1997) are envisaged. The Declaration of the World Medical Association on the Ethical Principles of Conducting Scientific Medical Research 
with Human Participation (1964-2000), and the Order of the Ministry of Health of Ukraine No. 281 of 01.11.2000, the Code of Ethics of the Scientist of Ukraine (2009). (Excerpt from Protocol No. 54 meetings Commission of Bioethics I. Horbachevsky Ternopil National Medical University Ministry of Health of Ukraine, from August, 2019). Prior to the survey, we received informed consent from all participants. The survey was conducted during the 2018-2019 school year.

\section{2. Methods of investigation of vestibular illusion of anti-rotation}

The duration of vestibular illusion of anti-rotation (VIA) was determined by the method of B. Tolokonnikov [8]. This method allows us to investigate the subjective sensations that arise during rectilinear and angular displacements, which provides information on the functional state of the sensory projection of the vestibular system, and the processes of interaction with other sensory systems that provide body equilibrium in space [9]. We classified the reaction into 4 levels: I - short (from 0.5 to 9 s.), II - average (from 10 to 19 s.), III - long (from 24 to 34 s.), IV - very long ( from $35 \mathrm{~s})$. The rotational test was carried out on the Barani chairs.

\section{3. Methods of investigation of neurodynamic features}

We used the computer system "Diagnostic-1M"(Ukraine) to study neuro-dynamic properi ties of a person. We measured the functional mobility of the nervous processes (FMNP) according to the rates of information processing in the "feedback" mode. With the help of optimal mode, we determined the minimum and maximum time of simple visual-motor reaction (SVMR) and latent periods of SVMR, the reaction of choice 1 of 3 (RCh 1-3), the reaction of choice 2 of 3 (RCh 2-3) [10]. The examination was carried out before and after the rotation test.

\section{4. Statisical Analysis}

Statistical data processing was performed using the nonparametric statistics methods: Wilcoxon's signed-rank test and the Mann-Whitney's U-test [11].

\section{Results}

The rate of processing information for a predetermined number of stimuli in groups I and II levels of VIA duration had a higher than in the groups with III and IV levels of VIA duration $(\mathrm{p}<0.05)$.

By the classification of M. Makarenko, the speed of processing information of a predetermined amount of stimuli in the group with I and II levels of VIA duration corresponded to higher than average; in the group with III and IV levels of VIA duration - the average level (Fig. 1).

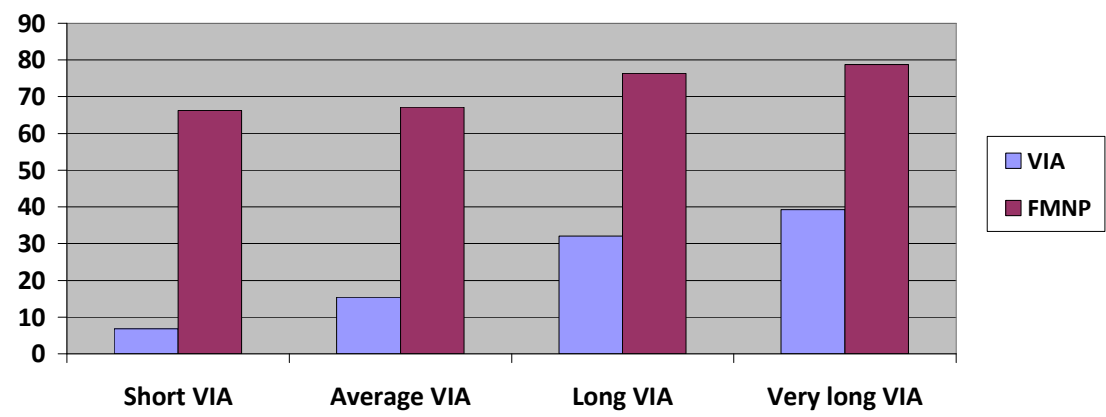

Fig. 1. FMNP of surveyed with different duration of VIA

Therefore, the relationship between the VIA duration and the level of FMNP is that the higher the VIA duration, the longer the processing time of a given number of stimuli, and the lower the level of FMNP.

During the study of the latency period of the SVMR at rest, the minimum time between groups I, II, III, and IV did not differ (Table 1). 
Table 1

Changes in SVMR after vestibular loading, depending on the VIA duration and FMNP level

\begin{tabular}{|c|c|c|c|c|c|c|}
\hline \multirow{2}{*}{$\begin{array}{c}\text { The duration of } \\
\text { the VIA }\end{array}$} & \multicolumn{2}{|c|}{ Minimum duration of the reaction } & \multirow{2}{*}{$\mathbf{P}$} & \multicolumn{2}{|c|}{ Maximum duration of the reaction } & \multirow{2}{*}{$\mathbf{P}$} \\
\hline & Before rotation & After rotation & & Before rotation & After rotation & \\
\hline $\begin{array}{c}\text { I level } \\
\text { n-8 }\end{array}$ & 157,97 & 147,74 & $\mathrm{p}<0,05$ & 561,49 & 601,76 & $\mathrm{p}<0,05$ \\
\hline $\begin{array}{c}\text { II level } \\
\mathrm{n}-20\end{array}$ & 158,07 & 149,04 & $\mathrm{p}<0,05$ & 561,49 & 603,76 & $\mathrm{p}<0,05$ \\
\hline $\begin{array}{c}\text { III level } \\
\text { n-19 }\end{array}$ & 158,64 & 162,77 & $\mathrm{p}<0,05$ & $788,15^{*}$ & $935,04 *$ & $\mathrm{p}<0,05$ \\
\hline $\begin{array}{c}\text { IV level } \\
n-13\end{array}$ & 159,83 & $165,77 * *$ & $\mathrm{p}<0,05$ & $793,15^{* *}$ & $945,06 * *$ & $\mathrm{p}<0,05$ \\
\hline
\end{tabular}

Notes: $p$-statistical significance of the T-criterion of Wilcoxon; *-the difference between the group with III levels of VIA duration and the groups with I and II levels of VIA duration; ** - the difference in the rates between the group with the IV levels of VIA duration and the groups with I and II levels of VIA duration

Also, from Table 1, we see that in a state of rest, the minimum period of SVMR between groups I, II, III and IV did not differ from the duration of VIA. The maximum time was significantly higher in the III and IV group than in the groups with I and II levels of VIA duration $(p<0.05)$. Comparing this indicator with the IV group, we did not find any difference. In the IV group, the maximum time was significantly higher than in the groups with I and II levels of VIA duration $(p<0.05)$.

After the vestibular loading in the group with I and II level of VIA duration, a decrease in the minimum reaction time $(\mathrm{p}<0,05)$ was observed, comparing it with the resting state. Regarding the maximum reaction time, we observed an increase in the response to the vestibular load $(\mathrm{p}<0.05)$. These changes indicate the activation of cortical processes, associated with greater expression of the orienting reflex.

In the group with III level of VIA duration, we observed an increase in the minimum and maximum response time after the vestibular load $(\mathrm{p}<0.05)$. Similar changes occurred in the group with IV level of VIA duration $(p<0,05)$. These changes are associated with the effects of vestibular stimulation and evidence of processes, inhibiting the activation of cortical processes. This indicates that vestibular irritation inhibits the processes of activation of the indicative response, in individuals with III and IV levels of VIA duration.

When comparing the indicators of the minimum and maximum time after the vestibular loading between the groups of the I and II level of VIA duration, we did not find any difference. Also, there was no significant difference between the groups with III and IV levels of VIA duration. However, we recorded higher rates in the groups with the III and IV level of VIA duration than in the groups with I and III of VIA duration $(\mathrm{p}<0.05)$.

The latent period in SVMR mode in resting conditions between groups did not differ and corresponded to the average level (Fig. 2).

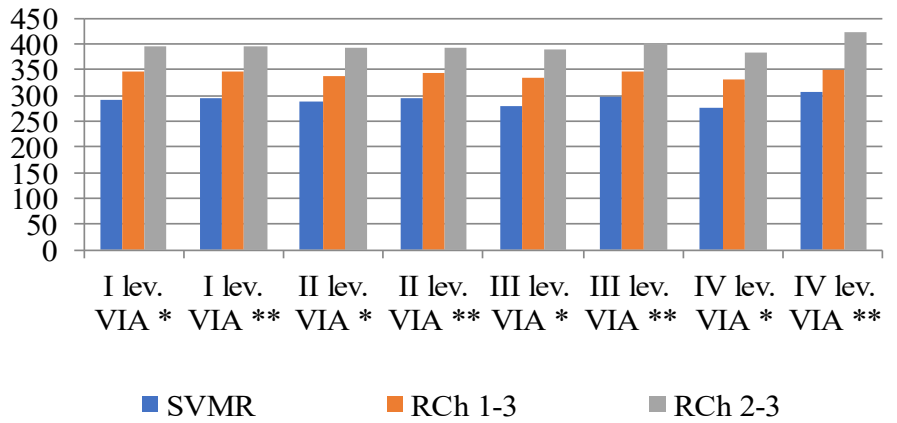

Fig. 2. The level of latent periods of sensorimotor reactions of varying complexity:

* -before rotation; ** - after rotation 
After vestibular loading, the index increased in groups with III and IV levels of VIA duration $(\mathrm{p}<0.05)$. When comparing the latent period after vestibular loading between the groups, depending on the VIA duration, in the groups with III and IV levels of VIA duration, the indicator was longer than in the groups with I and II level of VIA duration $(p<0,05)$.

Comparing the latent period in RCh 1-3 in the resting state between the groups, we did not detect the difference, and set the average response rate. After the vestibular load, we observed an increase in the rate in the groups with III and IV levels of VIA duration $(p<0.05)$. The latency period after the vestibular loading in the groups with III and IV levels of VIA duration was longer than in the groups with I and II levels of VIA duration $(\mathrm{p}<0.05)$.

In mode RCh 2-3 in a state of rest there were no differences. The level of sensory-motor response in all groups corresponded to the average. After vestibular loading, the index increased in groups with III and IV levels of VIA duration $(\mathrm{p}<0.05)$. The latency period after vestibular loading in the groups with III and IV levels of VIA duration was longer than in the groups with I and II levels of VIA duration $(\mathrm{p}<0.05)$ (Fig. 2).

The number of errors in the SVMR mode was minimal. In the mode of RCh 1-3 in a state of rest, the number of errors between groups did not differ (Fig. 3).

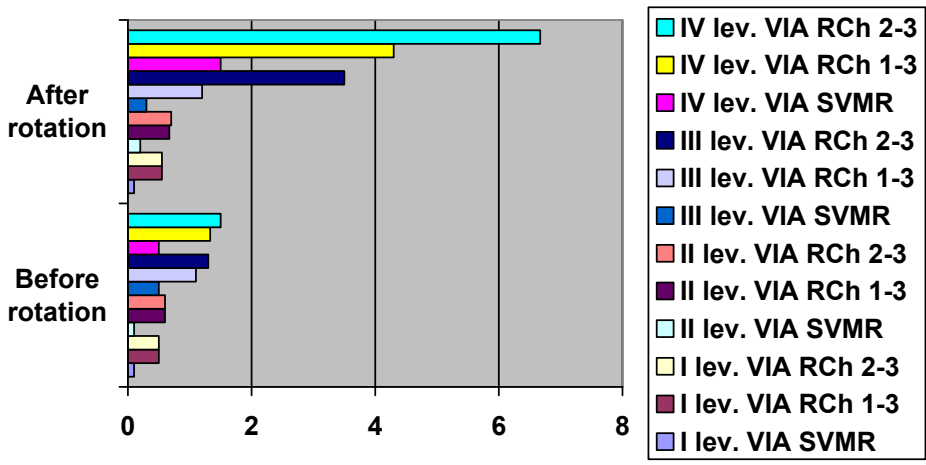

Fig. 3. Number of errors (\%) before and after the vestibular loading, depending on the duration of VIA and the level of optimal mode

After vestibular loading in RCh 1-3 mode, the number of errors in relation to the baseline status increased only in the IV group with the VIA duration $(\mathrm{p}<0.05)$, and was higher compared to the groups with I, II and III levels of VIA duration $(p<0.05)$.

The number of errors in mode RCh 2-3 in a state of rest between groups did not differ. After the vestibular load, the number of errors increased in the group with III and IV levels of VIA duration $(\mathrm{p}<0,05)$. After the vestibular load, the number of errors is higher in the groups with III and IV levels of VIA duration, when compared with I and II levels of VIA duration $(\mathrm{p}<0,05)$ (Fig. 3).

Lower levels of FMNP in individuals with III and IV levels of VIA duration than those with I and II, indicate a decrease in the ability to withstand long-term and concentrated excitation.

The lowering level of SVMR after vestibular loading in individuals with III and IV levels of VIA duration than with I and II levels suggests the activation of inhibition processes in response to the vestibular load.

The increase of errors after vestibular loading in the performance of RCh 1-3 and RCh 2-3 in individuals with IV level of VIA duration indicates a decrease in the accuracy of the sensorimotor response, which is carried out in the selection.

The absence of an increase in errors after vestibular loading in individuals with III level of VIA duration in the performance of RCh 1-3 and an increase in errors RCh 2-3 indicates a decrease in the accuracy of the sensorimotor response when complication of the task.

The results, obtained by us, are consistent with the findings of other authors, namely, that irritation of the vestibular analyzer reduces the excitability of other analyzers, disturbs the 
dynamics of processes in the cerebral cortex, decreases the accuracy of movements, impairs the ability to work, which is provided by the way, space orientation and vestibular memory $[12,13]$.

The vestibulo-sensory reactions are accompanied by a feeling of dizziness at irritation of vestibular nuclei. After rotation in the Barani chair, the reason is the imbalance between visual and vestibular irritations $[14,15]$; the objects are stationary, and the endolymph in the semicircular canals usually continues to move for $25-30 \mathrm{~s}$. in a healthy person, and with excessive excitability of the vestibular apparatus - up to 35-90 s. The manifestation of vestibulo-sensory reactions can also be darkening in the eyes [16]. This condition may be accompanied by general inhibition or irritability.

Therefore, the vestibular analyzer is a unique sensory organ, because it performs an integrative function, and the orientation of the receptor fields of the visual cortex changes upon stimulation of otolith receptors. This proves the effect of irritation of the semicircular canals on the activity of the visual cortex, as well as on the complex visual receptive field.

\section{Conclusions}

The relationship between the duration of vestibular illusion of anti-rotation and the level of functional mobility of nerve processes was established, which is that the higher the duration of vestibular illusion of anti-rotation, the lower the level of functional mobility of nervous processes.

During the study of sensorimotor reactions it was found, that the longest latency periods were in the subjects with very long vestibular illusion against rotation.

Features of neurodynamic processes in persons with the long duration of vestibular illusion of rotation, in the conditions of excitement of the vestibular analyzer, occur to a greater extent by increasing the duration of motor reactions and increasing the time of the reflex response.

The number of errors increases with increasing duration of vestibular illusion of rotation and complication of the task.

In the future, we plan to study the dynamics of brush movements after vestibular loading.

\section{References}

[1] Makarenko, N., Lizogub, V., Bezkopyl'niy, A. (2005). Formirovanie svoystv neyrodinamicheskih funktsiy u sportsmenov. Nauka v olimpiyskom sporte, 2, 80-86.

[2] Makarenko, M. V. (2006). Pryntsypy profesiynoho vidboru viyskovykh spetsialistiv ta metody vyvchennia indyvidualnykh psykhofiziolohichnykh vidminnostei mizh liudmy. Kyiv: Cherkaskyi TsNTEI, 395.

[3] Kreivinienè, B. (2016). Vestibular sensory dysfunction: neuroscience and psychosocial behaviour overview. Social welfare interdisciplinary approach, 6 (2), 184-197.

[4] Ashkinazi, S. Jagiello, W., Kalina, R. (2005). The importance of hand-to-hand fights for determining psychomotor competence of antiterrorists. Archives of Budo, 1 (1), 8-12.

[5] Moiseyenko, O., Gorchanyuk, Y., Gorchanyuk, V. (2015). Determination of the functional state of the vestibular analyzer volleyball players 14-15 years under the influence of a specially-designed exercises. Slobozans'kij Naukovo-Sportivnij Visnik, 2 (46), 133-137. doi: https://doi.org/10.15391/snsv.2015-2.026

[6] Multisensory Integration for Pilot Spatial Orientation (MIPSO) (2006). Available at: https://www.faa.gov/about/office_org/ headquarters_offices/avs/offices/aam/cami/library/online_libraries/aerospace_medicine/sd/media/Final\%20Report\%20 FA8650-04-C-6457.pdf

[7] Voropai, S., Burianovatyi, O. (2017) Pidvyshchennia vestybuliarnoi stiykosti biytsiv-bahatobortsiv na etapi pochatkovoi pidhotovky. Sportyvnyi visnyk Prydniprovia, 2, 40-43.

[8] Chinkin, A. S., Nazarenko, A. S. (2016). Fiziologiya sporta. Moscow: Sport, 120.

[9] Kryvsha, V. V. (2013). Osoblyvosti vestybulometrychnoho obstezhennia patsientiv z kokhleovestybuliarnymy labiryntnymy porushenniamy. Simeina medytsyna, 4 (48), 129-132.

[10] Makarenko, M. V., Lyzohub, V. S. (2003). Kompiuterna systema «Diahnost-1M» dlia vyznachennia neirodynamichnykh vlastyvostei vyshchoi nervovoi diyalnosti liudyny. Osoblyvosti formuvannia ta stanovlennia psykhofiziolohichnykh funktsii v ontohenezi: Matem. Ukr. sympozium nauk. Cherkasy, 60.

[11] Glantz, S. A. (2012). Primer of biostatistics. New York: McGraw-Hill Medical. 
[12] Soto, E., Vega, R. (2010). Neuropharmacology of Vestibular System Disorders. Current Neuropharmacology, 8 (1), $26-40$. doi: https://doi.org/10.2174/157015910790909511

[13] Bisdorff, A., Von Brevern, M., Lempert, T., Newman-Toker, D. E. (2009). Classification of vestibular symptoms: towards an international classification of vestibular disorders. Journal of Vestibular Research, 19 (1-2), 1-13. doi: https://oi.org/10.3233/ VES-2009-0343

[14] Schaaf, R. C., Lane, Sh. J. (2009). Neuroscience Foundations of Vestibular, Proprioceptive, and Tactile Sensory Strategies. OT Practice, 14 (22), CE1-CE7.

[15] Britton, Z., Arshad, Q. (2019). Vestibular and Multi-Sensory Influences Upon Self-Motion Perception and the Consequences for Human Behavior. Frontiers in Neurology, 10. doi: https://doi.org/10.3389/fneur.2019.00063

[16] Trinus, K. (2012). Vestibular system: morpho-physiology and pathology. Lambert Academic Publishing, 544.

Received date 12.09.2019

Accepted date 07.11.2019

Published date 30.11.2019
(C) The Author(s) 2019

This is an open access article under the CC BY license (http://creativecommons.org/licenses/by/4.0). 